\title{
Promising recent regenerative medicine applications in plastic and reconstructive surgery
}

\author{
Anas Eid ${ }^{1}$ and Jon P. Ver Halen ${ }^{1,2 *}$ \\ ${ }^{1}$ Department of Plastic and Reconstructive Surgery, Baptist Medical Group and Baptist Cancer Center, Memphis, Tennessee, USA \\ ${ }^{2}$ Vanderbilt-Ingram Cancer Center, Nashville, Tennessee, USA
}

\begin{abstract}
Cosmetic and reconstructive surgery relies extensively on the complex relationship between skin, soft tissue and the underlying bone skeleton. Soft tissue loss and acquired soft tissue deficits are some of the daily challenges faced by the plastic surgeon. Fat grafting has become one of the standard lines of care that has various applications in plastic surgery treatments. The ability of adipose stem cells to rejuvenate by producing trophic factors, and to differentiate into different cell types, has provided promising utilization for a variety of different applications in plastic surgery. Bone disorders, including infection and poor healing, pose vexing problems to the reconstructive surgeon. Vascular surgery is a technique necessary for the reconstruction of the most challenging surgical defects, and has great potential for improvement through technology. Nanoscale refinements of current techniques may offer more efficient and improved surgical and non-surgical approaches for reconstruction. Such refinements will significantly expand our capabilities for innovative reconstructive interventions, with high efficiency, specificity and minimal invasiveness.
\end{abstract}

\section{Introduction}

Cosmetic and reconstructive surgery relies extensively on the complex relationship between skin, soft tissue and the underlying bone skeleton. Soft tissue loss and acquired soft tissue deficits are some of the daily challenges faced by the plastic surgeon. Traumatic and oncologic bone defects, and complex defects requiring vascular reconstruction are similarly faced by plastic surgeons on a daily basis.

Extensive efforts have been made to develop various treatment options, techniques and approaches to achieve desirable results with minimal scarring, lower risks, less complications, and limited donor site morbidity. Fat grafting has become one of the standard lines of care that has various applications in plastic surgery treatments [1-6]. The ability of adipose stem cells to rejuvenate by producing trophic factors, and to differentiate into different cell types, has provided promising utilization for a variety of different applications in plastic surgery [717]. Existing fat grafting methods are associated with reported side effects including infections [7,18], calcifications [19] and inconsistent resorption ratios in tissue [20].

The most common form of bone regeneration is fracture healing, during which the pathway of normal fetal skeletogenesis is reactivated [21]. However, with substantial loss of bone tissue the regenerative process is compromised, as seen in cases of avascular necrosis and osteoporosis. These challenging situations often necessitate augmentation of natural bone repair. Most of the current strategies for bone regeneration exhibit relatively satisfactory results. However, there are associated drawbacks and limitations to their use and availability, and even controversial reports about their efficacy and costeffectiveness. Little has been reported on the use of nanobiomaterials as carrier materials for sustained release of growth factors in bone regeneration. One area of focus in nanotechnology is the delivery of osteogenic factors in an attempt to modulate the formation of bone.
The most significant anatomic defects often require reconstruction of not just bone and soft tissue, but also of vascular structures. Acute reconstruction requires the precise coaptation of arteries and veins without thrombosis and while maintaining patency. Long term success requires maintenance of patency and the prevention of significant vessel narrowing through atherogenesis or intimal hyperplasia. Endovascular techniques can significantly improve each of these phases.

Nanotechnology is the new state of the art that may offer more efficient and improved surgical and non-surgical approaches for skin and soft tissue reconstruction. The use of nanomaterial is minimally invasive, precise, multifunctional, and can be conducted in a very selective and controlled environment [22].

Nanoparticles are no longer limited to being drug carriers. They can be designed to carry highly specific physicochemical features, making them an excellent option for targeted therapy. The aim of this review is to summarize the recent patents in the nanotechnology field that carry some clinical significance in the treatment of soft tissue, that eventually may change the way we approach some reconstructive procedures [22,23].

\section{Methodology}

We searched the publically available and recently published and approved patents for the years 2012-2014. All patents that included regenerative medicine applications in the field of plastic surgery were

Correspondence to: Jon P Ver Halen, MD, FACS, Department of Plastic and Reconstructive Surgery, Baptist Medical Group and Baptist Cancer Center Research Member, Vanderbilt-Ingram Cancer Center, 3268 Duke Circle, Germantown, TN 38139, Tel: (206) 963-8714, Fax: (901) 227-9825; E-mail: jpverhalen@gmail.com

Received: May 02, 2015; Accepted: May 29, 2015; Published: June 03, 2015 
selected. Patents that had direct clinical application, or had a mature description that can be clinically relevant in the field of surgical reconstruction, were chosen for our review.

\section{Results and clinical applications}

\section{Fat grafting}

Fat grafting has become part of the standard lines of care in plastic surgery treatments. Mesenchymal adipose and endothelial stem cells are believed to be the main contributors to the various effects of fat grafting, including improved contour, quality of skin, and neovascularization [1,24-29]. The fat stem cells are highly proliferative and believed to be progenitors to variety of soft tissue, including osteoblasts, chondrocytes, myocytes, epithelial cells and neuronal cells. This creates a potential to treat a variety of tissue defects from a single and easily accessible cell source, with a relatively low donor site morbidity [13,30-36]. Fat grafting can be divided into 4 phases: procurement, processing, injection, and recipient site management [37].

\section{Improved cells quality and stability (Patent US 8512695 B2) [38]}

The presented patent uses Triblock polymers (poloxymer P188) mixed with the adipose tissue graft to stabilize the cell membranes of the cells, leading to less necrosis and more successful retain of transported fat. The patent targets stability of cells during procurement, handling of the graft and transplantation. The patent studied Triblock copolymers with a hydrophobic portion flanked by two other hydrophilic portions. The invention described compositions of polymers with central hydrophobic portion of P188 that interacts with the hydrophobic layer of the cell membrane, and the flanking hydrophilic ends of P188 locate themselves along the outer hydrophilic surface of the membrane. The Triblock copolymers thus seals and stabilizes the cell membrane preventing cell damage. The polymer is also descried to decrease the cellular viscosity, which makes the cells more soluble reducing the tension on the injured membranes.

The cells may be mixed with the polymer during processing just prior to injection, or before harvesting by injecting the donor site with a composition that includes the polymer. The patent also descried the addition of lipoic acid to the polymer; their investigation claims that lipoic acid addition has decreased the apoptosis of the fat cells compared to normal saline only. The patent claim shows a promising application that may decrease cell death and increase the viability of harvested and injected fat graft.

\section{Fat processing (Patent: US 8440440 B2) [39]}

This patent addresses the extraction of stem cells from liposuctioned fat. Despite early concerns over the quality of harvested fat using ultrasonic harvest techniques, recent research comparing it to traditional technique showed no significant difference in stem cell content. Traditional techniques rely on flow cytometry, FACS, or nanoscale cell sorting techniques to separate non-stem cell (e.g., CD $13,29,31$ ) from stem cell populations (e.g., CD 3,34). This patent focuses on treating the aspirate ex vivo with ultrasonic cavitation. This is done in a controlled environment and for a sufficient amount of time. Nanoscale refinemens of the ultrasound probe allow more precise delivery of ultrasonic waves into the harvested tissue, allowing selective destruction of fat and blood cells, while preserving the stromal fraction containing stem cells. The cavitation lyses fat and other aspirated cells while preserving stromal, mesenchymal and endothelial stem cells. The broken components are washed out providing a concentrated pure stem cells aspirate. If this patent shows reliability and no undesirable effects by the concentrated stem cells; this technique may make fat grafting a more powerful tool for soft tissue reconstruction, tissue regeneration, wound healing, and soft tissue augmentation.

\section{Improved fat survival (Patent WO2014152629 A1) [40]}

Neovascularization is a critical component in long-term survival and regeneration of transferred fat. This patent concentrates on the use of tissue signals to mobilize and recruit bone marrow derived vasculogenic progenitor cells to the site of injection. The progenitor cells stimulate neovascularization and regeneration of the transferred tissue. The patent described the use of Stromal Cell Derived Factor1 (SDF-1) as a mobilization factor with either concurrent or interval fashion administration. The inventors also described the use of this chemotactic agent as a biopolymer, which is mixed with the harvested fat before injection. The biopolymer will then release the chemotactic agent over time without the need for reinjection. Specifically, the biopolymer takes the form of nanoscale polyglycolic and polylactic acid derivatives. This nanopolymer stabilizes the chemotactic agent an allows time- and location-specific controlled drug release. These biopolymers are administered as microspheres or implants. The described method is simple and can be easily integrated clinically. If the descried patent proved to be safe and effective, this nanoparticle integration may mean a more reliable fat grafting and less number of fat grafting session to achieve the desirable results.

\section{Precise micro-injection (Patent: US 20130310748 A1) [41]}

This invention does not utilize micro particles, however, it does use high definition CT scan imaging integrated with 3D microinjections. This is performed using an automated fat injection device. The injection unit is operated by a robotic arm system in a controlled speed. Fat grafts are injected into the subcutaneous layer with accurate, and effective manner without back and forth surgeon's arm movement. The device injects the harvested fat in three-dimensional layers and lines. This device resolves the issue of inconsistent placement, excess of fat grafts that may cause fat necrosis, unevenness of skin, or poor blood circulation. The automatic fat graft injection device allows fixed orientation, quantification, and constant pressure, thereby increasing the likelihood for survival of fat grafts with an easy approach. The robotic injection device utilizes preoperative CT scan for planning. This invention carries the potential to be another great tool that simplifies injection, and at the same time maximizes the outcomes of fat grafting.

\section{Fat removal}

\section{Patent US8298556-B2 [42]}

Surgical and non-surgical procedures for improving soft tissue contour and appearance have increased in prevalence. Liposuction is one of the most popular cosmetic surgery procedures for removing excessive fat deposits. Despite being a well-tolerated procedure, it is associated with significant adverse events that includes; bruising, swelling, numbness, soreness, infections, pigmentation, and friction burns. The procedure also carries more serious complications like the formation of fat embolism, excessive fluid loss, organ injury, and anesthetic toxicity [43].

Fat removal utilizing nanoscale drug delivery techniques provide a promising alternative to liposuction. Formulations containing nanoscale formulations of phosphatidylcholine and bile salts have been utilized to treat localized fat accumulations. Phosphatidylcholine is an 
essential component of cell membrane, and plays an important role in stability and repair of the membrane. Phosphatidylcholine and bile salts were used to reduce subcutaneous fat in the infraorbital region, thighs, abdomen, upper back, chin, and arms [44,45]. However, the aforementioned solutions come with some noticeable side effects like burning sensations, erythema, urticaria and variable degrees of pruritus, all of which usually resolve within a few days. More permanent sequelae including ulcerations, formation of granulomas, tissue necrosis and fibrosis are reported [44-46]. The exact mechanism of the solution is not completely understood. Reduction of adipose cell size, or acting as a detergent or emulsifying agent are hypothesized to be the cause of the observed effect [42].

This patent proves that bile salt solution alone does show similar effects, and can be used for non-surgical removal of localized fat deposits. The administration of bile salts alone provides similar effects on soft tissue without liposuction. The present patent describes a method for the non-surgical removal of localized fat deposits by administering phosphatidylcholine-free detergent compositions. The patent also described adding active anti-inflammatory and dispersion agents such as hyaluronidase or collagenase to enhance the activity and outcomes of this product. These detergent compounds, delivered in aqueous form, are produced using nanoscale fabrication techniques into specific micelles representing nanoscale drug delivery units.

\section{Bone and Implant-associated infection}

Implant-associated infectionis one of the most serious complications in orthopedic surgery. Bone infections associated with foreign body materials are especially difficult to treat. Removal of the infected implants $[47,48]$, long-term systemic antibiotic therapy, and multiple revisions with radical debridement are frequently required [49-51]. The consequences of infection can be devastating and may lead to prolonged hospitalization, poor functional outcome, sepsis, and even amputation [52].

Implant-associated infections are the result of bacteria adhesion to an implant surface and subsequent biofilm formation at the implantation site [53]. Formation of biofilm takes place in several stages, starting with rapid surface attachment, followed by multilayered cellular proliferation and intercellular adhesion in an extracellular polysaccharide matrix [54]. Bio-films are resistant to both the immune response and systemic antibiotic therapies.

Different surface modification strategies for orthopedic implants have been investigated, including (a) addition of materials of desired functions to the surface; (b) conversion of the existing surface into more desirable chemistries and/or topographies; and (c) removal of material from the existing surface to create new relevant topographies [55]. The latter, which was tested during in-vitro studies, provides the surface with a specific roughness to promote osteoblast proliferation and cell adhesion [56].

Coating metal implants with a bactericidal film would inhibit bacteria from colonizing implant surfaces and provide a high antibiotic concentration in a local region commonly found as a nidus for bacterial infection [57]. Different surface modifications and coating techniques can be used, such as direct impregnation with antibiotics [58] and immobilization of an antimicrobial agent in a matrix capable of binding to different surfaces [59], as well as coating with antimicrobial, active metals such as copper and silver [60] nitric oxide (NO)-releasing materials [61] and $\mathrm{TiO}_{2}$ films [62].

Active coatings for delivery of therapeutic molecules using the advantages of nanotechnology have a bright future. Implant-related microbial infection is a serious threat after orthopedic surgery. This method is very efficient because it decreases systemic toxicity and side effects of parenteral antibiotics, while also yielding higher drug concentration in the relevant tissues.

\section{Bone implants and drug-release systems}

One area of focus in nanotechnology is the delivery of osteogenic factors in an attempt to modulate the formation of bone. Research has focused on the use of biodegradable materials as scaffolds for cellular ingrowth, cell transplantation, or the delivery of therapeutic molecules as methods for regenerating osseous tissue.

Since Urist et al. [63] demonstrated that glycoproteins extracted from demineralized rabbit could induce bone formation in ectopic sites in tibia matrix rabbits and mice, tremendous advances have been made in the development of recombinant growth factors, proteins, and peptides for bone tissue regeneration. These factors have been shown to induce bone formation within a defect without the use of a carrier, but their relatively short half-lives necessitate the use of significant amounts of protein [64].

To increase the in vivo efficacy as well as reduce the quantities needed, the development of carriers capable of controlled, sustained delivery of proteins and peptides is desirable. In order to minimize surgical intervention required for the implantation of controlled release scaffolds, the development of materials that can be injected and cross-linked in situ would be desirable.

Much research effort has been committed to the investigation of ordered mesoporous silica materials in the biomedical field for two main reasons: their capability to regenerate bone tissue $[65,66]$ and their drug delivery possibilities $[67,68]$. When these silica-based ordered mesoporous materials are exposed to the physiological environment, a series of chemical reactions take place in the material-living tissue interface, which lead to the material incorporation into the living tissue. Available pore volume and surface play a key role in the protein loading capacity of silica-based ordered mesoporous materials. If large biomolecules, such as certain proteins, are targeted to be adsorbed in ordered mesoporous materials, these matrices should present several characteristics: 1) large size pores size to allow diffusion; 2) high surface to allow a large retention percentage; 3 ) high pore volume to offer available space into the mesopores to be filled by the protein.

Several natural and synthetic polymers have been explored for use as delivery vehicles for bone inductive molecules. The poly(a-hydroxy acid) family of polymers including poly(lactic acid) (PLA), poly(lacticco-glycolic acid) (PLGA), and their copolymers have been the focus of much of this research as they are biocompatible, undergo controllable hydrolytic degradation into natural metabolites, and can be processed into many forms [69,70]. In addition, microparticles of PLA and PLGA have been used to deliver many factors including TGF-1 and BMP-2 into osseous defects [71]. Finally, porous PLGA scaffolds have also been developed to provide support for cellular migration. Some of this work focused on the adsorption of therapeutic agents onto prefabricated scaffolds, but control of the factor's release kinetics was found to be limited with this technique.

\section{Patents 8304220 and 8278094}

Both of these patents describe methods for delivering one or more biologically active molecules or cells to a subject. The methods are comprised of one or more devices constructed of a porous bone 
Table 1. Description of patents referenced in the current article.

\begin{tabular}{|l|l|}
\hline Patent US 8298556-B2 & Methods and related compositions for the non-surgical removal of fat \\
\hline Patent US 8440440-B2 & $\begin{array}{l}\text { Ultrasonic cavitation derived stronal or mesnchymal vascular extracts and cells derived therefrom obtained from adipose tissue and } \\
\text { use thereof }\end{array}$ \\
\hline Patent WO 2014152629-A1 & Combination therapy to improve soft tissue healing, fat graft healing, endochondral bone healing and osteointegration \\
\hline Patent US 20130310748-A1 & Automatic fat graft injection device with navigation system \\
\hline Patent US 8298556-B2 & Methods and related compositions for the non-surgical removal of fat \\
\hline Patent US 8304220-B2 & Bone semi-permeable device \\
\hline Patent US 8278094-B2 & $\begin{array}{l}\text { Formed by combining an implantable bone structure configured to form an internal cavity and a semi-permeable membrane such that } \\
\text { an internal cavity is maintained; for delivering one or more biologically active molecules and/or one or more living cells or tissues } \\
\text { to a subject }\end{array}$ \\
\hline Patent US 8287937-B2 & Endoprosthese \\
\hline
\end{tabular}

structure including a plurality of holes therein and a semi-permeable membrane which covers at least a portion of the plurality of holes prior to implantation, the porous bone structure at least partially forming an internal cavity. The cavity contains one or more biologically active molecules or cells, and are selectively permeable through the semi-permeable membrane. In some embodiments, the pore size is approximately any integer $\mathrm{nm}$ from 1 to 10,000 including, but not limited to, $2 \mathrm{~nm}, 3 \mathrm{~nm}, 4 \mathrm{~nm}, 5 \mathrm{~nm}, 8 \mathrm{~nm}, 10 \mathrm{~nm}, 12 \mathrm{~nm}, 15 \mathrm{~nm}, 20$ $\mathrm{nm}, 25 \mathrm{~nm}, 50 \mathrm{~nm}, 100 \mathrm{~nm}, 200 \mathrm{~nm}, 300 \mathrm{~nm}, 500 \mathrm{~nm}, 600 \mathrm{~nm}, 800 \mathrm{~nm}$, $1,000 \mathrm{~nm}, 2,000 \mathrm{~nm}, 5,000 \mathrm{~nm}$, or $10,000 \mathrm{~nm}$. In other embodiments, the pore size is approximately $1 \mathrm{~nm}$ to $10,000 \mathrm{~nm}, 10 \mathrm{~nm}$ to $5,000 \mathrm{~nm}$, $25 \mathrm{~nm}$ to $1,000 \mathrm{~nm}, 50 \mathrm{~nm}$ to $750 \mathrm{~nm}, 100 \mathrm{~nm}$ to $500 \mathrm{~nm}, 10 \mathrm{~nm}$ to 100 $\mathrm{nm}, 5 \mathrm{~nm}$ to $50 \mathrm{~nm}, 1 \mathrm{~nm}$ to $10 \mathrm{~nm}, 2 \mathrm{~nm}$ to $20 \mathrm{~nm}, 500 \mathrm{~nm}$ to 5,000 $\mathrm{nm}, 1,000 \mathrm{~nm}$ to $10,000 \mathrm{~nm}$, or $250 \mathrm{~nm}$ to $1,000 \mathrm{~nm}$ in width. In some embodiments, the pore size is not uniform throughout the structure. The purpose of this device is, amongst others, to deliver localized doses of a bioactive agent for the potential treatment of deep tissue infection, or disorders of bone healing, as outlined in the preceding section.

\section{Vascular reconstruction}

The most significant anatomic defects often require reconstruction of not just bone and soft tissue, but also of vascular structures. Acute reconstruction requires the precise coaptation of arteries and veins without thrombosis and while maintaining patency. Long term success requires maintenance of patency and the prevention of significant vessel narrowing through atherogenesis or intimal hyperplasia. Endovascular techniques can significantly improve each of these phases.

\section{Patent 8287937}

This patent describes an intravascular stent with a coating having a smooth orange peel morphology is formed on an adluminal surface of a stent, concurrently with the formation of a coating having a rough rice grain morphology on an abluminal surface of the stent. During the formation of the two coatings, a mandrel is placed adjacent to the adluminalsurface of the stent but does not generally contact the adluminal surface. The first coating and the second coating can be formed using physical vapor deposition, glancing angle deposition, or sputtering. The first and second coatings can include a metal, for example, tantalum, chromium, titanium, or iridium, or a ceramic, for example, titanium nitride, titanium oxide, titanium oxi-nitride, or iridium oxide. The first coating can have a thickness of about $10 \mathrm{~nm}$ to about $50 \mathrm{~nm}$. The second coating can have a thickness of about $200 \mathrm{~nm}$ to about $300 \mathrm{~nm}$.

Embodiments of this patent may include one or more of the following advantages. Stents can be formed with ceramic coatings that have morphologies and/or compositions that enhance therapeutic performance. In particular, the ceramics are tuned to enhance mechanical performance and physiologic effects. Enhanced mechanical performance provides particular advantages during the challenging operations encountered in stent use, which typically includes collapsing the stent to a small diameter for insertion into the body, delivery though a tortuous lumen, and then expansion at a treatment site. Enhancing mechanical properties of the ceramic reduces the likelihood of cracking or flaking of the ceramic, and enhances adhesion of the ceramic to the stent body and to overcoatings, such as drug eluting materials. Improved physiologic effects include discouraging restenosis and encouraging endothelialization. The ceramics are tuned by controlling ceramic morphology and composition. For example, the ceramic can have a morphology that enhances endothelial growth, a morphology that enhances the adhesion of overcoatings such as polymers, e.g., drug eluting coatings, a morphology that reduces delamination, cracking or peeling, and/or a morphology that enhances catalytic activity to reduce inflammation, proliferation and restenosis. The ceramic coatings can be tuned along a continuum of their physical characteristics, chemistries, and roughness parameters to optimize function for a particular application. Different coating morphologies can be applied in different locations to enhance different functions at different locations. For example, a high roughness, low coverage, defined-grain morphology can be provided on abluminal surfaces to enhance adhesion of a drug-eluting polymer coating and a low roughness, high coverage, globular morphology can be provided on the luminal surface to enhance endothelialization. The composition is tuned to control hydrophobicity to enhance adhesion to a stent body or a polymer and/or control catalytic effects. The morphologies and composition can be formed by physical vapor deposition using methodologies that allow fine tuning of the morphology characteristics and permit highly uniform, predictable coatings across a desired region of the stent. Further, the two morphologies can be provided to different locations simultaneously or sequentially without taking the stent out of the deposition system, therefore, potential contamination due to vacuum breakdown and long operation time can be reduced or avoided.

\section{Future directions and conclusion}

Regenerative medical techniques offer multiple future promising applications for soft tissue reconstruction. However, more research is needed to examine the interaction of various materials with different body systems. The biodistribution, safety, and long-term consequences need to be evaluated further prior to their clinical application.

The small size and possible infiltration of nanoparticles allow them to penetrate tissue, migrate in the body, and possibly accumulate in various organs or cells. More research is needed to fully understand 
the pharmacokinetics and dynamics of these structures, and therefore their applications. However, nanotechnology will significantly expand our capabilities for innovative reconstructive interventions, with high efficiency, specificity and minimal invasiveness.

\section{References}

1. Coleman SR (2001) Structural fat grafts: the ideal filler? Clin Plast Surg 28: 111-119. [Crossref]

2. Arcuri F, Brucoli M, Baragiotta N, Stellin L, Giarda M, et al. (2013) The role of fat grafting in the treatment of posttraumatic maxillofacial deformities. Craniomaxillofac Trauma Reconstr 6: 121-126. [Crossref]

3. Cárdenas-Camarena L, Lacouture AM, Tobar-Losada A (1999) Combined gluteoplasty: liposuction and lipoinjection. Plast Reconstr Surg 104: 1524-1531. [Crossref]

4. de Pedroza LV (2000) Fat transplantation to the buttocks and legs for aesthetic enhancement or correction of deformities: long-term results of large volumes of fat transplant. Dermatol Surg 26: 1145-1149. [Crossref]

5. Perén PA, Gómez JB, Guerrerosantos J, Salazar CA (2000) Gluteus augmentation with fat grafting. Aesthetic Plast Surg 24: 412-417. [Crossref]

6. Longo B, Laporta R, Sorotos M, Pagnoni M, Gentilucci M, et al. (2014) Total breast reconstruction using autologous fat grafting following nipple-sparing mastectomy in irradiated and non-irradiated patients. Aesthetic Plast Surg 38: 1101-1108. [Crossref]

7. Castelló JR, Barros J, Vázquez R (1999) Giant liponecrotic pseudocyst after breast augmentation by fat injection. Plast Reconstr Surg 103: 291-293. [Crossref]

8. Kamakura T, Ito K (2011) Autologous cell-enriched fat grafting for breast augmentation. Aesthetic Plast Surg 35: 1022-1030. [Crossref]

9. Lee HC, An SG, Lee HW, Park JS, Cha KS, et al. (2012) Safety and effect of adipose tissue-derived stem cell implantation in patients with critical limb ischemia: a pilot study. Circ J 76: 1750-1760. [Crossref]

10. Lendeckel S, Jödicke A, Christophis P, Heidinger K, Wolff J, et al. (2004) Autologous stem cells (adipose) and fibrin glue used to treat widespread traumatic calvarial defects: case report. J Craniomaxillofac Surg 32: 370-373. [Crossref]

11. Matsumoto D, Sato K, Gonda K, Takaki Y, Shigeura T, et al. (2006) Cell-assisted lipotransfer: supportive use of human adipose-derived cells for soft tissue augmentation with lipoinjection. Tissue Eng 12: 3375-3382. [Crossref]

12. Rigotti G, Marchi A, Galiè M, Baroni G, Benati D, et al. (2007) Clinical treatment of radiotherapy tissue damage by lipoaspirate transplant: a healing process mediated by adipose-derived adult stem cells. Plast Reconstr Surg 119: 1409-1422. [Crossref]

13. Shen CC, Yang YC, Liu BS (2012) Peripheral nerve repair of transplanted undifferentiated adipose tissue-derived stem cells in a biodegradable reinforced nerve conduit. J Biomed Mater Res A 100: 48-63. [Crossref]

14. Thesleff T, Lehtimäki K, Niskakangas T, Mannerström B, Miettinen S, et al. (2011) Cranioplasty with adipose-derived stem cells and biomaterial: a novel method for cranial reconstruction. Neurosurgery 68: 1535-1540. [Crossref]

15. Warnke PH, Springer IN, Wiltfang J, Acil Y, Eufinger H, et al. (2004) Growth and transplantation of a custom vascularised bone graft in a man. Lancet 364: 766-770. [Crossref]

16. Yoshimura K, Sato K, Aoi N, Kurita M, Hirohi T, et al. (2008) Cell-assisted lipotransfer for cosmetic breast augmentation: supportive use of adipose-derived stem/stromal cells. Aesthetic Plast Surg 32: 48-55. [Crossref]

17. Yoshimura K, Sato K, Aoi N, Kurita M, Inoue K, et al. (2008) Cell-assisted lipotransfer for facial lipoatrophy: efficacy of clinical use of adipose-derived stem cells. Dermatol Surg 34: 1178-1185. [Crossref]

18. Valdatta L, Thione A, Buoro M, Tuinder S (2001) A case of life-threatening sepsis after breast augmentation by fat injection. Aesthetic Plast Surg 25: 347-349. [Crossref]

19. Huch RA, Künzi W, Debatin JF, Wiesner W, Krestin GP (1998) MR imaging of the augmented breast. Eur Radiol 8: 371-376. [Crossref]

20. Eremia S, Newman N (2000) Long-term follow-up after autologous fat grafting: analysis of results from 116 patients followed at least 12 months after receiving the last of a minimum of two treatments. Dermatol Surg 26:1150-1158. [Crossref]

21. Ferguson C, Alpern E, Miclau T, Helms JA (1999) Does adult fracture repair recapitulate embryonic skeletal formation? Mech Dev 87: 57-66. [Crossref]
22. Parks J 4th, Kath M, Gabrick K, Ver Halen JP (2012) Nanotechnology applications in plastic and reconstructive surgery: a review. Plast Surg Nurs 32: 156-164. [Crossref]

23. Walia B, Satija N, Tripathi RP, Gangenahalli GU (2012) Induced pluripotent stem cells: fundamentals and applications of the reprogramming process and its ramifications on regenerative medicine. Stem Cell Rev 8: 100-115. [Crossref]

24. Garza RM, Paik KJ, Chung MT, Duscher D, Gurtner GC, et al. (2014) Studies in fat grafting: Part III. Fat grafting irradiated tissue--improved skin quality and decreased fat graft retention. Plast Reconstr Surg 134: 249-257. [Crossref]

25. Soejima K, Kashimura T, Asami T, Kazama T, Matsumoto T, et al. (2015) Effects of mature adipocyte-derived dedifferentiated fat (DFAT) cells on generation and vascularisation of dermis-like tissue after artificial dermis grafting. J Plast Surg Hand Surg 49: 25-31. [Crossref]

26. Kanchwala SK, Holloway L, Bucky LP (2005) Reliable soft tissue augmentation: a clinical comparison of injectable soft-tissue fillers for facial-volume augmentation. Ann Plast Surg 55: 30-35. [Crossref]

27. Bucky LP1, Kanchwala SK (2007) The role of autologous fat and alternative fillers in the aging face. Plast Reconstr Surg 120: 89S-97S. [Crossref]

28. Khouri R, Del Vecchio D (2009) Breast reconstruction and augmentation using preexpansion and autologous fat transplantation. Clin Plast Surg 36: 269-280. [Crossref]

29. Khouri RK, Smit JM, Cardoso E, Pallua N, Lantieri L, et al. (2013) Percutaneous aponeurotomy and lipofilling: a regenerative alternative to flap reconstruction? Plast Reconstr Surg 132: 1280-1290. [Crossref]

30. Zuk PA, Zhu M, Ashjian P, De Ugarte DA, Huang JI, et al. (2002) Human adipose tissue is a source of multipotent stem cells. Mol Biol Cell 13: 4279-4295. [Crossref]

31. di Summa PG, Kalbermatten DF, Pralong E, Raffoul W, Kingham PJ, et al. (2011) Long-term in vivo regeneration of peripheral nerves through bioengineered nerve grafts. Neuroscience 181: 278-291. [Crossref]

32. Higuchi A, Chuang CW, Ling QD, Huange SC, Mei L, et al. (2011) Dif- ferentiation ability of adipose-derived stem cells separated from adipose tissue by a membrane filtration method. J Membr Sci 366: 286-294.

33. Gimble JM, Guilak F, Bunnell BA (2010) Clinical and preclinical translation of cellbased therapies using adipose tissue-derived cells. Stem Cell Res Ther 1: 19. [Crossref]

34. Strem BM, Hicok KC, Zhu M, Wulur I, Alfonso Z, et al. (2005) Multipotentia differentiation of adipose tissue-derived stem cells. Keio J Med 54: 132-141. [Crossref]

35. Zuk PA, Zhu M, Mizuno H, Huang J, Futrell JW, et al. (2001) Multilineage cells from human adipose tissue: implications for cell-based therapies. Tissue Eng 7: 211-228. [Crossref]

36. Brayfield C, Marra K, Rubin JP (2010) Adipose stem cells for soft tissue regeneration. Handchir Mikrochir Plast Chir 42: 124-128. [Crossref]

37. Del Vecchio D, Rohrich RJ (2012) A classification of clinical fat grafting: different problems, different solutions. Plast Reconstr Surg 130: 511-522. [Crossref]

38. William G, Austen JR (2013) Method of preventing fat graft resorption by administering fat-derived cells and poloxamer P 188, US 8512695 B2.

39. Steven Victor (2013) Ultrasonic cavitation derived stromal or mesenchymal vascular extracts and cells derived therefrom obtained from adipose tissue and use thereof US 8440440 B2.

40. Leonard B Miller (2014) Stephen Warren. Combination therapy to improve soft tissue healing, fat graft healing, endochondral bone healing and osteointegration WO 2014152629 A1.

41. Ming-Huei Cheng (2013) Automatic Fat graft injection device with Navigation System US 20130310748 A1.

42. Michael S Kolodney, Adam M Rotunda (2012) Methods and related compositions for the non-surgical removal of fat US $8298556 \mathrm{~B} 2$.

43. Hanke CW, Bernstein G, Bullock S (1995) Safety of tumescent liposuction in 15,336 patients. National survey results. Dermatol Surg 21: 459-462. [Crossref]

44. Aasadi M, Sales AP, Motamedi B (2004) Mesoplasty: a new approach to non-surgical liposculpture. Plastic Surgery 2004, Philadelphia, PA.

45. Ablon G, Rotunda AM (2004) Treatment of lower eyelid fat pads using phosphatidylcholine: clinical trial and review. Dermatol Surg 30: 422-427. [Crossref]

46. Schuller-Petrovic S, Wölkart G, Höfler G, Neuhold N, Freisinger F, et al. (2008) Tissuetoxic effects of phosphatidylcholine/deoxycholate after subcutaneous injection for fat dissolution in rats and a human volunteer. Dermatol Surg 34: 529-542. [Crossref] 
47. Sanderson PJ (1989) Preventing infection in orthopaedic implants. J Antimicrob Chemother 24: 277-280. [Crossref]

48. Taylor GJ, Bannister GC, Calder S (1990) Perioperative wound infection in elective orthopaedic surgery. J Hosp Infect 16: 241-247. [Crossref]

49. Darouiche RO (2004) Treatment of infections associated with surgical implants. NEngl $J$ Med 350: 1422-1429. [Crossref]

50. Anderson JM (2001) Biological responses to materials. Ann Rev Mater Res 31: 81-110.

51. An YH, Friedman RJ (1996) Prevention of sepsis in total joint arthroplasty. $J$ Hosp Infect 33: 93-108. [Crossref]

52. Calhoun JH, Manring MM (2005) Adult osteomyelitis. Infect Dis Clin North Am 19: 765-786. [Crossref]

53. Zilberman M, Elsner JJ (2008) Antibiotic-eluting medical devices for various applications. J Control Release 130: 202-215. [Crossref]

54. Trampuz A, Osmon DR, Hanssen AD, Steckelberg JM, Patel R (2003) Molecular and antibiofilm approaches to prosthetic joint infection. Clin Orthop Relat Res 69-88. [Crossref]

55. Duan K, Wang R (2006) Surface modifications of bone implants through wet chemistry. $J$ Mater Chem 16:2309-2321.

56. Linez-Bataillon P, Monchau F, Bigerelle M, Hildebrand HF (2002) In vitro MC3T3 osteoblast adhesion with respect to surface roughness of Ti6Al4V substrates. Biomol Eng 19: 133-141. [Crossref]

57. Li H, Ogle H, Jiang B, Hagar M, Li B (2010) Cefazolin embedded biodegradable polypeptide nanofilms promising for infection prevention: A preliminary study on cell responses. J Orthop Res 28:992-999. [Crossref]

58. Tasman AJ, Wallner F, Neumeier R (2000) Antibiotic impregnation of cartilage implants: diffusion kinetics of fluoroquinolones. Laryngorhinootologie 79: 30-33. [Crossref]

59. Copello GJ, Teves S, Degrossi J, D'Aquino M, Desimone MF, et al. (2006) Antimicrobial activity on glass materials subject to disinfectant xerogel coating. $J$ Ind Microbiol Biotechnol 33: 343-348. [Crossref]
60. Bosetti M, Massè A, Tobin E, Cannas M (2002) Silver coated materials for external fixation devices: in vitro biocompatibility and genotoxicity. Biomaterials 23: 887-892. [Crossref]

61. Nablo BJ, Prichard HL, Butler RD, Klitzman B, Schoenfisch MH (2005) Inhibition of implant-associated infections via nitric oxide release. Biomaterials 26: 6984-6990. [Crossref]

62. Chung CJ, Lin HI, Tsou HK, Shi ZY, He JL (2008) An antimicrobial TiO2 coating for reducing hospital-acquired infection. J Biomed Mater Res B Appl Biomater 85: 220-224. [Crossref]

63. Urist MR, Mikulski A, Lietze A (1979) Solubilized and insolubilized bone morphogenetic protein. Proc Natl Acad Sci U S A 76: 1828-1832. [Crossref]

64. Wozney JM, Rosen V, Byrne M, Celeste AJ, Moutsatsos I, et al. (1990) Growth factors influencing bone development. J Cell Sci Suppl 13: 149-156. [Crossref]

65. Vallet-Regí M, Ruiz-González L, Izquierdo-Barba I (2006) Revisiting silica based ordered mesoporous materials: medical applications. J Mater Chem 16: 26-31.

66. Vallet-Regí M (2006) Bone repair and regeneration possibilities. Mater-wiss u Werkstofftech 37: 478-484.

67. Vallet-Regí M (2006) Ordered mesoporous materials in the context of drug delivery systems and bone tissue engineering. Chemistry 12: 5934-5943. [Crossref]

68. Vallet-Regí M, Balas F, Arcos D (2007) Mesoporous materials for drug delivery. Angew Chem Int Ed Engl 46: 7548-7558. [Crossref]

69. Athanasiou KA, Niederauer GG, Agrawal CM (1996) Sterilization, toxicity, biocompatibility and clinical applications of polylactic acid/polyglycolic acid copolymers. Biomaterials 17: 93-102. [Crossref]

70. Jain RA (2000) The manufacturing techniques of various drug loaded biodegradable poly(lactide-co-glycolide) (PLGA) devices. Biomaterials 21: 2475-2490. [Crossref]

71. Shive MS, Anderson JM (1997) Biodegradation and biocompatibility of PLA and PLGA microspheres. Adv Drug Deliv Rev 28: 5-24. [Crossref]

Copyright: (C2015 Eid A. This is an open-access article distributed under the terms of the Creative Commons Attribution License, which permits unrestricted use, distribution, and reproduction in any medium, provided the original author and source are credited. 